\title{
Involving women in research for economic growth through agricultural technologies and practices: ICRISAT's initiatives in sub-Saharan Africa
}

Hakeem A. Ajeigbe ${ }^{1}$

Chanda Gurung Goodrich ${ }^{2}$

Bonny R. Ntare

Eva Weltzien ${ }^{4}$

Jupiter Ndjeunga ${ }^{5}$

${ }^{1}$ ICRISAT Kano

PMB 3491

Sabo Bakin Zuwo Road

Tarauni

Kano

Nigeria

$<$ H.Ajeigbe@cgiar.org >

2 ICRISAT

Patancheru 502324

Andhra Pradesh

India

<c.goodrich@cgiar.org>

3 ICRISAT

PO Box 320

Bamako

Mali

$<$ b.ntare@cgiar.org >

4 ICRISAT

PO Box 320

Bamako

Mali

<eva.weltzien@gmail.com>

5 ICRISAT

PO Box 12404

Niamey

Niger

$<$ n.jupiter@icrisatne.ne >

$<$ n.jupiter@cgiar.org $>$

Reprints : H. Ajeigbe

\section{Abstract}

Although both men and women play substantial economic roles in the semi-arid tropics of sub-Saharan Africa (SSA), in general women's preponderant role in agricultural activities in the region cannot be ignored. Cultural norms in the region have long encouraged women to be economically self-reliant and traditionally give women substantial responsibility for agricultural production in their own right. Women in the region have relatively high overall labour-force participation rates and the highest average agricultural labour-force participation rates in the world. Thus, women farmers in the region, irrespective of their ethnic group, substantially contribute to national agricultural production and food security as they are primarily responsible for food crops - food production as well as processing. As an agricultural research institute ICRISAT's initiatives and programs are technology based; and as gender empowerment is high on ICRISAT's agenda, most if not all of its projects and programs aim at addressing women with new technologies and knowledge to reach higher agricultural outputs. These, combined with other income generating activities are implemented with an aim to increase women's income and thus their autonomy and status. In this paper we have taken some major ICRISAT initiatives in some countries of Western Central Africa (Mali, Niger and Nigeria) to look in to the implications for economic growth - for women and their families. Three major initiatives led by ICRISAT are reported here: the Groundnut seed project (2003-2007), Tropical Legumes II in first phase (2008-2010), and the Harnessing Opportunities for Productivity Enhancement (HOPE) of Sorghum and Millets in sub-Saharan Africa and South Asia (2009-2012). All these projects have specific activities targeting women and involve technology and crop/seed management practices that were intentionally women-centric with the aim of enhancing women's capacities and skills in the traditional tasks that they were responsible for, viz. cultivation of crops and seed production.

Key words : agricultural technologies, economic growth, gender, sub-Saharan Africa, women.
To cite this article: Ajeigbe HA, Goodrich CG, Ntare BR, Weltzien E, Ndjeunga J, 2013. Involving women in research for economic growth through agricultural technologies and practices: ICRISAT's initiatives in sub-Saharan Africa. Sécheresse 24: 359-66. doi: 10.1684/sec.2013.0405 
Impliquer les femmes dans la recherche sur la croissance économique par le biais de technologies et pratiques agricoles : les initiatives de I'ICRISAT en Afrique sub-saharienne

Bien qu'hommes et femmes jouent un rôle économique substantiel dans les tropiques semi-arides d'Afrique (SSA), le rôle prépondérant des femmes dans les activités agricoles ne peut être ignoré. Les normes culturelles de la région ont longtemps poussé les femmes à être économiquement indépendantes et donnent traditionnellement à la femme une responsabilité centrale dans la production agricole. Les femmes représentent une part importante de la force ouvrière agricole, en proportion la plus importante au monde. Ainsi, les femmes de la région, indépendamment de leur appartenance ethnique, principales responsables de la production et transformation des denrées agricoles, contribuent à une part essentielle de la production agricole nationale et de la sécurité alimentaire. Les initiatives et programmes de l'ICRISAT, institut de recherche agricole, sont basés sur la technologie ; comme l'égalité des genres est importante pour l'agenda de I'ICRISAT, la plupart des projets et programmes se focalisent sur les femmes et leur accès aux technologies nouvelles et à a connaissance pour augmenter la production agricole. Ces dernières, combinées à $d^{\prime}$ autres activités génératrices de revenus, sont mises en place afin $d^{\prime}$ 'augmenter le revenu des femmes, et partant, leur autonomie et leur statut. Dans cet article, nous passons en revue les différentes initiatives de I'ICRISAT dans plusieurs pays de 'Afrique de l'Ouest (Mali, Niger, et Nigeria) afin de dégager ce qu'elles impliquent en termes de croissance économique pour les femmes et leur famille. Trois initiatives principales sont examinées : le projet graines d'arachide (2003-2007), le projet légumineuses tropicales (TLII, 2008-2010), et le projet sur l'amélioration de la productivité du sorgho et du mil en Afrique et Asie (HOPE, 2009-2012). Tous ces projets ont des activités spécifiques ciblant les femmes et impliquent l'usage de technologies et la gestion des semences et des cultures, activités choisies consciemment comme étant centrées sur les activités habituelles des femmes, afin $d^{\prime}$ augmenter leur capacités pour ces tâches qu'elles assument traditionnellement.

Mots clés : Afrique sub-saharienne, croissance économique, femmes, genre, technologies agricoles.

$\mathrm{T}$ he semi-arid tropics of subSaharan Africa (SSA) are among the poorest regions in the world with the Human Development Index (HDI) of 0.463 , average life expectancy of 54 years, mean years of schooling as 4.4 , and $\mathrm{GNI}$ per capita (constant 2005 PP\$) of 1966 (UNDP, 2011). This region is home to a host of innumerable ethnic groups and cultures. With $64 \%$ of the population living in rural areas, the mainstay of the region is agriculture; agriculture represents 20 to $30 \%$ of GDP and $50 \%$ of exports, in some cases, 60 to $90 \%$ of the labor force are employed in agriculture (World Bank, 2011 ). Numerous crops have been domesticated in the region and spread to other parts of the world. These crops included sorghum, castor, beans, coffee, cotton, okra, black-eye peas, watermelon, gourd, peas, pearl millet, rice, yams, kola nuts, oil palm, and raffia palm (National Research Council, 1996; Vandaveer, 2006). Cash crops include cotton, coffee, tea, cocoa, sugar, and tobacco (Bowden, 2007). The other main source of income is from livestock products such as meat and milk products.

However, the subsistence small holder farmers of the region have limited access to modern improved technologies and their general circumstance does not always merit tangible investments in capital, inputs and labour (Ogunlela and Mukhtar, 2009). Thus, "the ultimate need for development - through entitlement and empowerment" (Ribot et al., 1996) is most urgently needed here.

Although both men and women play substantial economic roles, in general women's preponderant role in agricultural activities in the region cannot be ignored. Women in the region have relatively high overall labour-force participation rates and the highest average agricultural labour-force participation rates in the world. Cultural norms in the region have long encouraged women to be economically self-reliant and traditionally give women substantial responsibility for agricultural production in their own right. Ogunlela and Mukhtar (2009) point out that African family and inheritance systems combine to produce an agricultural system which assigns the major role to women. However, there also exists marked subregional variations in men's and women's share of work; for instance in much of the Sahel, men are predominant in agriculture, including in the food sector (Muntemba and Blackden, 2000). A number of countries have seen substantial increases in the female share of the agricultural labour force in recent decades due to a number of reasons, including conflict, HIV/AIDS and migration. A wide variety of literature is available on the critical role that rural women play within this sector and the data speaks for itself. Women account for approximately $70 \%$ of sub-Saharan agricultural workers producing two-thirds of food crops, and for about $80 \%$ of food processors (Wakhungu, 2010). FAO (2006) estimates that in sub-Saharan Africa and the Caribbean women produce as much as $80 \%$ of basic foods.

Women play an important role not only in the cultivation but also in processing and small-scale traditional agricultural production, for instance:

Post-harvest: in many cultures of the region, women's responsibilities are primarily post-harvest (transport, threshing, cleaning and storage) and processing, for both home consumption and local marketing.

Production: in some areas, particularly in West and Central Africa, women are also deeply involved in the production segment of the value chain. They manage 
their own production fields, although in most cases their land tenure depends on the husband's decisions, providing both incomes for themselves and a food security reserve for their children.

Processing: Women dominate the processing sector for many crops, both in the home, and for traditional food marketing.

Marketing: Women often generate income from marketing products processed or derived from the crops; although women are more visible in the marketing of perishable products like leaves as vegetables, and seed and small-scale processing (e.g., groundnuts for home and local sale), while men tend to dominate the grain marketing in the value chain (Bationo et al., 2011) and few highly commercialized production contexts such as common bean in the central rift valley of Ethiopia and the lowlands of northern Tanzania.

Thus, women farmers in the region, irrespective of their ethnic group, substantially contribute to national agricultural production and food security as they are primarily responsible for food crops food production as well as processing. Consequently, women's rights to productive assets - not only land and livestock but also new technology are central to overcoming poverty and inequality.

\section{Gender and technologies}

The gender-technology question in agriculture is of special relevance at this juncture of time, when agricultural development projects, with the goal of agricultural improvement and poverty reduction are focused on the development and distribution of new and advanced technologies ranging from improved crop varieties, fertilizers, agricultural implements/tools, irrigation technologies, and processing technologies. In more recent years biotechnology has been advocated to create high yield, pest and environmentally resistant crops in the hands of small farmers. It is often assumed by most, including those involved in the development and transfer of technology, that technologies and the process (of development and technology transfer) is gender-neutral. However, this is not the case as most often technology has implications on gender aspects, such as men and women's agricultural productivity, efficiency, drudgery in terms of time and labor, income, health, etc., and also on the adoption of the technology and the production economy. Further to this, Guyer (1984) noted the introduction of agricultural technologies often reshape social relationships to exert control over the production process. Thus, technologies need to fit the physical and sociocultural conditions of end-users - men or women depending upon who is actually engaged in that task. Therefore, it is imperative to have a gender lens in regard to technology in all its aspects - in relation to particular technologies, the crosscutting issues arising from a range of technologies, and to the process of technology transfer. Questions on what assumptions are being made in the process of technology development, the design, manufacture, marketing and the use of products, whether women are involved in decision-making process of technological development and whether and how such development is transforming gender relations and women's work, are of particular relevance (Muntemba and Blackden, 2000).

Numerous examples exist to show the gendered impacts of technology, some of which are given in the following subsections.

\section{Productivity}

A common method of measuring agricultural productivity is based on output per hectare of land or yield. Several studies based on this method, covering a wide range of countries in Africa and a few in other regions, found that women's yields were lower than men's for a variety of crops (Quisumbing, 1996; Peterman et al., 2010). A majority of these studies did not consider the resource gaps women farmers face in their cultivation practices. Some thorough recent studies and analyses in about 27 country studies on subSaharan Africa, came to the conclusion that gender differences in farm yields are caused primarily by differences between women and men in their access to agricultural inputs, technology and extension services (Horrell and Krishnan, 2007; Kumase et al., 2008).

\section{Workload and Income}

Adoption of fast cooking bean varieties in Tanzania has reduced the workload on women in terms of time spent in search of firewood, cooking, and foraging for wild vegetables during the dry seasons (David and Sperling, 1999), and general consumption of annual firewood reduced by about 10\% (Nkonya et al., 1998). On the other hand, the negative impacts were observed in the form of increased workload on women by the adoption of soil improvement technologies, such as planting and incorporating green manure alongside varieties. ICRISAT's study also shows that the increase in groundnut production resulting from new varieties and technologies led to increases in household incomes, but a greater workload for women in shelling the increased production (Feldstein, 1998).

\section{Adoption}

Men and women have different roles and responsibilities within households and agriculture. Research has shown that due to this gender differentiated roles and responsibilities, women and men frequently have distinct varietal preferences, which can have implications on adoption of varieties. In Zambia's Northern Province a government-developed groundnut variety, MGV4, was widely introduced yet failed catastrophically because it is very oily and hard to pound, and produces an unpleasant-tasting relish. It was assumed that the large-sized nut would be easy to grind for groundnut oil, but due to a lack of consultation with women the multiple uses of groundnuts had not been considered, nor had, incidentally, the lack of processing facilities and a ready market for oil (Farnwort et al., 2011). Added to this are the gender differences in technology choices which have been reported in participatory legume variety evaluation studies (e.g., Kolli and Bantilan, 1997). Transfer of technology is another critical aspect that needs to be looked at with a gender lens. Programme outcomes are frequently biased in advance against women by assuming homogeneity of interests within or between households. Whereas in reality households are not unitary with a single interest or equality (Sen, 1990; Agarwal, 1994; Kabeer, 1997; Kelkar et al., 2003; Rao, 2006; Deere and Doss, 2006), rather household gender relations profoundly affect not only the control and power over the household income and assets interests of individuals but also their needs, interests and constraints. However, extension and other technology support systems continue to direct a greater proportion of technical assistance and extension services to men, even for tasks and crops that women manage, in the assumption that information will be shared. As a consequence, information about new techniques and upgrading may not flow to the right person. This can result in decreased volume and product quality and poorer returns to the work of both women and men in value chains. 
These and any other examples, clearly show the close linkage between gender and technology, and the importance of fully incorporating gender issues into technology development and transfer.

\section{ICRISAT-led initiatives}

\section{About ICRISAT}

The International Crops Research Institute for the Semi-Arid Tropics (ICRISAT) is a non-profit and non-political agricultural research institute. It is headquartered in Hyderabad in India and runs seven regional centers in Kenya, Zimbabwe, Malawi, Mozambique, Niger, Mali, and Nigeria. ICRISAT envisions prosperous, food-secure and resilient dryland tropics. Its mission is to reduce poverty, hunger, malnutrition and environmental degradation in the dryland tropics. ICRISAT uses science as a means to serve the poor through better agricultural production systems in the dry tropics of Asia and sub-Saharan Africa. Therefore, besides developing and improving crop genes, production systems and natural resource management ICRISAT is also concerned about income generation and empowerment of the poor and vulnerable, including women to overcome poverty. ICRISAT's programs are focused on achieving six development outcomes, namely: food sufficiency, crop intensification, crop diversification, resilience, health and nutrition, and women's empowerment. ICRISAT implements research programs in ways that benefit smallholder farmers enabling them and their families to go beyond subsistence farming to produce surpluses that can be stored and sold to markets, paving the way for prosperity in the drylands. ICRISAT takes the position that gender is an essential element of its overall agenda and attaches great importance to the gender implications of its research and training activities. There is an emphasis on incorporating the gender implications in all project proposals and reporting to enhance sensitivity and knowledge on women's work and economic contributions. The Inclusive Market-Oriented Development (IMOD) conceptual framework that underlies ICRISAT's Strategic Plan to 2020 (ICRISAT, 2010) categorically mentions that it "will enable the poor, particularly women, to participate and benefit rather than be sidelined" in the economic growth.
Major initiatives and their implications

Being an agricultural research institute ICRISAT's initiatives and programs are technology based. Since gender empowerment is high on ICRISAT's agenda, and most, if not all of its projects and programs aim at addressing women with new technologies and knowledge to reach higher agricultural outputs. These, combined with other income generating activities are implemented with an aim to increase women's own income and thus their autonomy and status. In this paper we have taken some major initiatives of ICRISAT in some countries of Western Central Africa (Mali, Niger, and Nigeria) to look in to the implications for economic growth - for women and their families.

Three major initiatives led by ICRISAT that are reported here are the Groundnut seed project (2003-2007), Tropical Legumes II in first phase (2008-2010) and the Harnessing Opportunities for Productivity Enhancement (HOPE) of Sorghum and Millets in sub-Saharan Africa and South Asia (2009-2012). All these major projects have specific activities targeting women.

\section{- Mali}

ICRISAT's core research areas in Mali are agronomy, pearl millet, sorghum, and groundnut breeding, with a specific focus on market-orientated production and value addition. To accomplish these goals, ICRISAT Mali has set up and executed several farmer field schools and participatory plant breeding projects. Within these projects, farmers are directly involved in the development, testing and evaluation of different varieties. ICRISAT makes use of several tests fields in certain villages where the farmers they work with have planted different types of sorghum and millet.

\section{Sorghum}

Sorghum is traditionally considered a men's crop in most West-Africa countries. It is usually the responsibility of the head of the household to ensure that the family has sufficient grain of this staple food available, on a daily basis, while women tend to grow crops that can be used as accompaniment of the staple. In addition they tend to be responsible for collecting firewood and drawing water (Savane, 1986; Vierich, 1986).

ICRISAT initiated a survey in 2007 of rural women and sorghum cultivation in southern Mali (Dioila and Kati districts, 6 villages each, with 86 individual interviews, and 12 group discussions
[Van den Broek, 2007]). It showed that all the women interviewed were also growing sorghum in their own fields allocated for their use on a seasonal basis). They grew sorghum as an intercrop in their groundnut fields, as well as sole crops. Thus the quantity of sorghum produced by one woman varied substantially. However, the distribution of the use of the sorghum grain was quite homogeneous: approximately $50 \%$ of women were used to provide additional meals for young children. During the lean period, when men had heavy field work to do, they also received food from the woman's grain stock. The other half of their production was sold, usually as small quantities throughout the year, to generate cash for other household purchases, such as salt, sugar, or school supplies for the children (Van den Broek, 2009). This study also indicated that women have no access to the family farmyard manure for use in their own fields, even though these fields tend to be the lower fertility fields. Women were found to be experimenting with the use of pre-emergence herbicides as well as very small doses of fertilizer. Even though the women were part of households and villages which had participated in variety trials with sorghum, only few of them were aware of this, and even less had gained access to the seeds of these varieties. A followup survey conducted in 2009 in the Mande area, south-west of Bamako, had similar findings, and developed a strategy with the women, for greater involvement in the sorghum variety development efforts (Donovan, 2010). This strategy was implemented as part of the HOPE project ${ }^{\dagger}$ implementation in

\footnotetext{
${ }^{1}$ The HOPE seeks to help smallholder farmers increase the yields of the two dryland cereal crops, sorghum and millet, in West Africa Mali, Burkina Faso, Niger, and Nigeria), Eastern Africa (Sudan, Ethiopia, Eritrea, Uganda, Kenya, and Tanzania) and India (Rajasthan, Haryana, Gujarat, and Maharashtra).The poor in these target areas are among the most food-insecure in the world, unable to earn adequate incomes from agriculture. Lack of adaptive approaches to increasing their productivity combined with shrinking markets have spelt doom for dryland farmers, most of who are still in subsistence farming. The vicious circle of less production and less market demand has led to poor investment and support to dryland agriculture. ICRISAT, working with a wide array of partners, is addressing this decline by stimulating research on sorghum and millet farming, enhancing technology utilization, linking farmers with markets, and strengthening the capacity of national and civil society partners along an inclusive market-oriented development pathway.
} 
Mali. The key elements of this strategy are:

- to work with women who are already organized in a village or commune level group or cooperative;

- to identify of sorghum varieties that meet women's needs in terms of crop adaptation, as well as grain qualities;

- to identify opportunities for soil fertility improvement that are within women's reach.

The objective of ICRISAT's HOPE project is to accelerate measures towards attaining gender equality and women's empowerment through their rights to productive resources in semi-arid agricultural production especially in the sorghum- and millets-based production systems where a majority of them are engaged. The project also envisaged that exposure of women to the latest technical knowhow in farming coupled with their capacity building through trainings and demonstrations would enable them to take up diversified market-oriented activities in the farm, including livestock and small ruminants, thus, improving overall productivity of the farming system (ICRISAT, 2009).

Since 2009, women's groups in three regions in Mali have been actively testing sorghum varieties with diverse agronomic options for improving sorghum yield, as an intercrop, or as a sole crop. Sorghum variety preferences of the women tend to consider traits such as adaptation to low soil fertility, reduced bird attacks, good grain storage and processing characteristics, as well as limited shading of the intercrop, mostly groundnut.

Among the agronomic options that women decided to evaluate were new spatial arrangements of sorghum as an intercrop, i.e. densely sown double rows; using wood ash as fertilizer, placed in the planting hole at sowing time and micro-dosing with mineral fertilizer of the sorghum rows in the intercrop. The women are keen to increase their sorghum grain production, even with some penalties of groundnut productivity in the same fields, to ensure food security for their children.

One of the most preferred varieties of the women is an improved local variety, Dovaje, which has been identified as being specifically adapted to low soil phosphorus conditions, as well as high in grain iron and zinc. This research has thus opened an impact pathway for a bio-fortified sorghum variety which could benefit young children directly. Some of the villages where the variety trials are now ongoing are presently also involved in nutrition training activities.
Some of the women's groups have also started to become seed producers. A women's group in Siby has joined the seed cooperative, COOPROSEM (Coopérative des producteurs de semence du Mande) and is engaged in producing seeds of open-pollinated varieties. The women's cooperative in Wacoro, which is a member of ULPC (Union locale des producteurs de céréales de Dioila), is starting in the 2013 to produce sorghum hybrid seeds, in addition to groundnut (see below), cowpea and maize seeds, on contract basis with a woman-owned seed marketing firm, based in Bamako (Dalohoun et al., 2011 1).

Thus, this initiative has led to women not only earning income but also becoming players in the seed production and supply.

\section{Groundnut}

Another major initiative by ICRISAT has been in groundnut which is the major source of income for millions of rural households in West Africa. While cereal farming is an activity undertaken and managed by men, groundnut is a woman's crop in many countries in the region - in Mali, more than $50 \%$ of the groundnut plots belong to women. However, women face a range of constraints to groundnut production including poor access to suitable land (land where men can hardly grow anything), poor access to family labour (only when men have finished planting), poor access to seeds of modern varieties as many projects often target only men, poor access to fertilizers and poor access to credit because of lack physical or social collateral owned by women. Several studies on household dynamics showed that women's contribution to household welfare is very important especially as women feed the family and invest in children health and education. Thus, a marginal involvement of women in the groundnut commodity value chain is likely to bring larger impacts on households' members. Following this analysis during the last 10 years, ICRISAT and partners have initiated a range of programs/projects to empower women in rural communities with focus on promotion of groundnut varieties, seed production and marketing. Specifically two groundnut seed projects, including the Groundnut seed project (2003-2007) aimed at the development of sustainable groundnut seed systems in West Africa and implemented in Mali, Niger, Nigeria, and Senegal. The second was the
Tropical Legumes II with the objective to enhance legumes productivity in drought prone areas of sub-Saharan Africa and South Asia ${ }^{2}$ in the first phase (2008-2010). These projects were developed and implemented with a wide range of research and development partners (research institutes, the extension services, agro-dealers, seed quality assessment institutions, rural radios and individual and women's associations) in Mali, Niger, and Nigeria. The methodology in both projects included participatory variety selection by women farmers using a mother and baby trial design; training of women farmers and seed producers in seed production technologies; training women farmers in small-scale business management and marketing skills; establishing linkages between seed producers, traders or agro-dealers including input shop dealers were established; formally registering individual producers and women's associations as small-scale seed companies; establishing linkages between the national agricultural research institutes and individual women farmers and farmers' associations; establishing linkages between women's associations and rural radios to facilitate the dissemination of information on varieties and seeds sold, the location of seed sales and groundnut crop management techniques. The implementation of this initiative brought about many positive changes in the women's lives in Wakoro (Mali), including directly involving them in the economic growth.

Women of Wakoro, used to grow groundnuts without much success until, Ms. Mariam Coulibaly from the village of Wakoro in Dioila district of Mali accompanied by four other women

\footnotetext{
$\overline{2}$ Tropical Legumes-Il is a joint initiative of three international agricultural research centres, viz. ICRISAT (chickpea, groundnut and pigeonpea), Internationa Institute of Tropical Agriculture ([IITA] cowpea \& soybean), and International Center for Tropical Agriculture ([CIAT], common bean) that aims to increase productivity and production of legumes and the income of poor farmers in sub-Saharan Africa (SSA) and South Asia (SA) by $15 \%$, with improved varieties occupying $30 \%$ of the total area planted by some 57 million poor farmers in the coming 10 years. It is expected that this will result in an additional value gain of more than US\$300 million during that period. The project's strategy is to fast track testing and adoption of existing varieties and advanced breeding lines for use by famers; generate new farmer- and marketpreferred varieties and hybrids with desirable traits (high yields, tolerance to moisture stress, and resistance to pests and diseases); and establish decentralized, pro-poor seed production and delivery systems.
} 
visited ICRISAT station at Samanko in 2001. They were impressed by three varieties (ICGV 86124, Fleur 11 and $J L 24)$ that were on display in a demonstration plot. The following year these five women were supplied with $1 \mathrm{~kg}$ seed each of the three varieties, which they grew in plots measuring $10 \times 10 \mathrm{~m}$ under the technical guidance of ICRISAT staff. After harvest they kept all the seeds of each variety and shared these with other women in the village. Impressed with the yields and earliness of the varieties Mariam requested the village chief to allocate them a larger piece of land on which they could multiply their three varieties. This encouraged them to form an association called Bankora. By 2008 membership of the association had grown to 195 women. Through this community-based seed production (CBSP) approach, the women farmers of Wakoro have been able to access seeds at the local level at cheaper rate as well as enhance their skills in quality seed production and seed marketing. They have become self-sufficient for groundnut seeds and a significant quantity of seeds is sold outside the district. For example in 2008 , the association sold 2 tons of seeds to the neighbouring Republic of Guinea and in 2012 they produced 9.5 tons of groundnut seeds and sold all. Due to increasing demand for seed the women farmers have also been able to increase their income and food security. Their status and decision making has also improved. The woman group has now ventured into using a warrantee system including cereal grain sales to the World Food Program.

Following this success and the success of this initiative in Niger (given below), the scheme was operationalized in five villages in the Koulikoro region, involving 150 women through the partnership between ICRISAT and Plan Mali. It was started in 2009 in two neighbouring villages and was extended to three more villages in 2010. Five groundnut varieties (ICGV 86124, ICGV 86024 , ICGV 85015, ICG 7878, Fleur 11) were made available and grown in plots of 0.1 hectare per variety. Preference assessment showed that over all ICGV 86024, ICGV 86124 and Fleur 11 were the most preferred across the 5 villages. Their pod yield varied between $600 \mathrm{~kg} / \mathrm{ha}$ to $2,045 \mathrm{~kg} / \mathrm{ha}$ with the best yield obtained in the initial two villages. The average yield advantage of the introduced varieties over the local variety ranged from 15 to $25 \%$. The exposure to the new varieties has heightened enthusiasm of the women's groups in the Plan Mali Intervention zone with prospects for income generation as well as improved nutrition of the children and their mothers.

\section{- Niger}

A similar initiative in groundnut was done in Niger where groundnut is also a major source of income for rural households. Again as in Mali, in Niger too while cereal farming undertaken and managed by men, groundnut is a woman's crop in, with more than in $40 \%$ of the groundnut plots belonging to women. These women face similar range of constraints in groundnut production - poor access to suitable land, labour, seed of modern varieties, fertilizers, and credit. With the two major initiatives, i.e. the Groundnut seed project (2003-2007) and the Tropical Legumes II (2008-2010), in partnership with research and development partners in the country, the CBSP (communitybased seed production) described above was implemented in which a total of 16 women's associations with total of 694 members, and 89 women smallscale seed producers were involved in the Dosso region. The major outcome of these interventions was women empowerment seed production and delivery.

A range of activities were undertaken under the initiatives. During the Groundnut seed project, in 6 villages in the Dosso region, using participatory varietal selection, using mother and baby trial approach, was conducted, in which the three varieties - RRB, ICG 9346, and $\mathrm{J} 11$ - stood out to be preferred by women farmers because of higher pod yield, early maturity, higher number of pod per plant, and good pod filling as well as their suitability to make processed products (cakes and oil) (Ndjeunga and Ibro, 2010). The three varieties were used as basis to develop the community-based seed production and delivery schemes. Sixteen women's associations and 89 individual smallscale farmers women's groups were trained in seed production technology, small business management and marketing skills. A marketing strategy of sale of small pack seeds was implemented linking farmers to agro-dealers. Varieties and seeds were promoted through local radios. The National Agricultural Research Institute in Niger (INRAN) and ICRISAT were to supply breeder seeds to women's associations and individual small-scale farmers. During the last four years of pilot experiments, the women engaged in the $C B O$ seed production schemes produced more than 100 tons of certified groundnut seeds in 20102011 -about $65 \%$ of the total groundnut certified seeds produced in $\mathrm{Niger}^{3}$ - and the quality is very good. In three years (2008-2009 to 2010-2011), 243 tons of groundnut seeds were produced and sold by women's associations and individual women farmers in the Dosso region of Niger.

- Nigeria

One of the initiatives under the HOPE project, ICRISAT partnering with a local NGO, the Green Sahel Agricultural and Rural Development Initiative (GSARDI), has been successful in truly involving women for economic growth through technologies and practices, as this initiative has increased the sales, income, profit and employment of women's processor groups based in Jigawa state. A SWOT (Strength-Weakness-Opportunity-Threat) analysis and need assessment showed that the major entry points to the value chain in need of upgrading included:

a) poor access to high quality grain due to current sourcing from the open market;

b) high processing costs due to inefficient traditional cooking stones that also create cleaning and health challenges because of the high release of carbon soot on the cooking materials;

c) limited storage capacity for processed products;

d) poor quality products due to improper packaging and product presentation.

ICRISAT teamed up with GSARDI to support the women's groups through training in hygiene and sanitation, the use of energy-saving stoves, and by linking them with sorghum and millet producers' groups and Celsian Mills Ltd, of Gumel. The project also helped the women's group in obtaining a deep freezer, modern cooking stove, utensils and electric generator.

All these training and equipment quickly generated increased income for the group comprising 25 women processors led by Hajia Zainab Mai-Fura. From processing just 50 to $100 \mathrm{~kg}$ of millet per day and selling only fura, Haija Zainab now processes 150 to $250 \mathrm{~kg}$ of millet per day and has doubled sales income to US\$4,000-6,000 a month from US $\$ 1,800-2,600$. Diversification has introduced new products, which include fura ball, fura coarse powder, fura mixed with yogurt or milk, and milk or yogurt on their own. Sales of the fresh products have become possible thanks

\footnotetext{
${ }^{3}$ Republic of Niger, Ministry of Agriculture and Livestock. Directory on the Availability of Improved Seed. 2010-2011.
} 
to the provision of a generator for refrigeration and modernization has improved cleanliness in other ways. In addition, employment increased too prior to the ICRISAT intervention, Haiia Zainab and her group employed 6 daily workers, but now employs an average of 10 workers ( 6 women and 4 men) per day. During festival periods, or when there are important meetings and events in and around Gumel, up to 20 workers can be required to cope with the additional demand for fura and other products. Hajia Zainab has renovated her own shop and bought other equipment such as milling machines. She notes that her profit margin has increased tremendously thanks to an energy-efficient stove that consumes less fuel and has improved product hygiene sufficiently to attract non-traditional customers. She points out that her success has been noticed by other processing groups, including sellers of tuwo flour dumplings whom she is assisting to mill sorghum and millet. Now the group is handling more cash, she believes the next steps for the group should include training in business development, as well as linkages to the National Agency for Food and Drug Administration and Control (NAFDAC) for certification. This will allow them to package of their products for sale to other parts of the country.

\section{Conclusion}

The above initiatives involving technology and crop/seed management practices were intentionally women-centric with the aim of enhancing women's capacities and skills in the traditional tasks that they were responsible for, viz. cultivation of crops and seed production. The establishments of proper linkages in the value chain and exposure to new technologies and practices have been the driving forces for the success in making visible the women's involvement in economic growth. However, this is not to say that women were not involved in the economic growth prior to this or when they were not making much income.

Women's involvement in the economy and economic growth is not to be seen only in terms of income and production. Economic growth needs to be looked at from a larger perspective which involves two critical arenas:

a) Contributions of men and women in the entire production cycle - As mentioned in the beginning, a distinguishing characteristic of sub-Saharan African economies is that both men and women play substantial economic roles. However, many empirical studies show that women are more active than men in agriculture, particularly in food crop production, marketing, and processing of agricultural products. Thus, it is imperative to capture the dynamics of the varied contributions of men and women to the productive economy considering the "gender intensity of production" of different sectors (Elson and Evers, 1997);

b) The equally important non-market arena that provides the base for economic growth - The different structural gendered roles of men and women found in the economy (notably in agriculture and the informal sector) is compounded with equally unbalanced gendered roles in the household economy, where women shoulder most of the domestic tasks and responsibilities (Ellis et al., 2006). However, this entire role of women in the household economy is even today largely invisible and uncounted giving rise to the misconception that women are not fully involved in the economic growth.

Of course all this stems from the overall gender inequality, which acts as a powerful constraint to (economic) growth - macro analysis, case studies, and analysis of demographic linkages, asset inequality, and labour constraints all indicate that there is a strong connection between gender inequality and growth. Thus, removing genderbased barriers would make substantial contributions to economic growth and efficiency and not just to promote equity and justice. The above initiatives cited were all in these lines, where the gender inequalities and barriers against women were removed by targeting women as the main partners, thus creating an enabling environment where their contribution in the more "formal and mainstream" economic growth could be visible and counted for.

\section{References}

Agarwal B, 1994. A field of One's Own: Gender and Land Rights in South Asia. Cambridge: Cambridge University Press.

Bationo A, Waswa B, Okeyo JM, Maina F, Kihara J, Mokwunye U, 2011 eds. Fighting poverty in Sub-Saharan Africa: The multiple roles of legumes in integrated soil fertility management. 1 st edition. Berlin; Heidelberg: Springer.

Bowden R, 2007. Africa South of the Sahara. Mankato (Minnesota, USA): Capstone Publishers.

Dalohoun DN, Van Mele P, Weltzien E, Diallo D, Guinda H, vom Brocke K, 2011. Mali: When
Government Gives Entrepreneurs Room to Grow. In : Van Mele P, Bentley JW, Guéi RG, eds. African seed enterprises. Sowing the seeds of food security. Rome; Cotonou: FAO; AfricaRice.

David S, Sperling L, 1999. Improving technology delivery mechanisms: lessons from bean seed systems research in Eastern and Central Africa. Agriculture and Human Values 6 : 381-8.

Deere CD, Doss CR, 2006. The Gender asset gap: What do we know and why does it matter? Feminist Economics 12 : 1-50.

Donovan M, 2010. Disseminating seeds of innovation and empowerment: Strategies for achieving a gender sensitive participatory plant breeding program in Mali, West Africa. Professional Studies in International Agriculture and Rural Development, MSc. Thesis, Cornell University.

Ellis A, Manuel C, Blackden CM, 2006. Gender and economic growth in Uganda unleashing the power of women. Washington (DC): The International Bank for Reconstruction and Development/The World Bank.

Elson D, Evers B, 1997. Gender-aware country economic reports. Working Paper No. 2. Uganda. Task Force on Programme Aid and Other Forms of Economic Policy-Related Assistance. University of Manchester, United Kingdom.

FAO, 2006. Agriculture, trade negotiations and gender. FAO Gender and Population Division. A contribution of the FAO Gender and Population Division to the UN interagency publication on Gender and Trade: Challenges and Opportunities, 2004. In collaboration with the FAO Trade and Commodities Division. Rome: FAO. (Prepared by Zoraida Garcia).

Farnwort CR, Akamandisa VM, Hichaambwa M, 2011. Zambia Feed the Future Gender Assessment. Zambia: USAID.

Feldstein, 1998. An inventory of gender-related research and training in the consultative group on international agricultural research (CGIAR) centers 1996-1998. http://www.PRGA POGRAM. ORG accessed on 20 July 2011.

Guyer Jl, 1984. Naturalism in models of African production. Man 19 : 371-88.

Horrell S, Krishnan P, 2007. Poverty and productivity in female-headed households in Zimbabwe. Journal of Development Studies $43: 1351-80$.

ICRISAT, 2010. ICRISAT Strategic Plan to 2020: Inclusive Market-Oriented Development for Smallholder Farmers in the Tropical Drylands. Patancheru (Andhra Pradesh, India): International Crops Research Institute for the Semi-Arid Tropics (ICRISAT).

Kabeer N, 1997. Women, wage and intrahousehold power relations in urban Bangladesh. Development and Change 28 : 261-302.

Kelkar G, Nathan D, Walters P, eds. Gender relations in forest societies: Patriarchy at odds. Thousand Oaks (California): Sage Publications.

Kolli RD, Bantilan MCS, 1997. Gender-related impacts of improved agricultural technologies: Identification of indicators from a case study. Gender Technology and Development 1 : 37193. 
Kumase WN, Bisseleua H, Klasen S, 2008. Opportunities and constraints in agriculture: a gendered analysis of cocoa production in southern Cameroon. Discussion Paper No. 27. Gottingen (Germany): Courant Research Centre "Poverty, Equity and Growth"; University of Gottingen.

Muntemba S, Blackden CM, 2000. Gender and Poverty in Africa. Background Paper for the CAPA/World Bank Conference on Poverty Alleviation in Africa Nairobi, Kenya, March 610, 2000.

National Research Council (U.S.), 1996. Board on Science and Technology for International Development. Lost Crops of Africa: Grains. Washington (DC): National Academy Press.

Ndjeunga J, Ibro A, 2010. Groundnut trends and prospects in West and Central Africa. Technical report, International Crops Research Institute for the Semi-Arid Tropics (ICRISAT). (Unpublished Paper).

Nkonya E, Ndakidemi P, Mushi C, Normman D, 1998. Adoption and environmental impact of an improved bean variety in Northern Tanzania. A paper submitted for presentation at the AFSRE Symposium, Pretoria, South Africa, $30 \mathrm{Nov}-4$ Dec 1998.

Ogunlela YI, Mukhtar AA, 2009. Gender issues in agriculture and rural development in nigeria: the role of women. Humanity \& Social Sciences Journal 4 : 19-30.
Peterman AJ, Behrman J Quisumbing AR, 2010. A review of empirical evidence on gender differences in nonland agricultural inputs, technology and services in developing countries. IFPRI Discussion Paper 00975. Washington (DC): International Food Policy Research Institute, Poverty, Health, and Nutrition Division (PHND).

Quisumbing AR, 1996. Male-female differences in agricultural productivity: Methodological issues and empirical evidence. World Development 24 : $1579-95$

Rao N, 2006. Women access and rights to land: gender relations in tenure- a scoping study in the India context. (Unpublished).

Ribot JC, Magalhaes AR, Panagides SS, eds. 1996; 2005. Social vulnerability in the semi-arid tropics. New York: Cambridge University Press.

Savane MA, 1986. The effects of social and economic changes on the role and status of women in Sub-Saharan Africa. In : Lewinger Mook J, (ed). Understanding Africa's rural households and farming systems. Boulder; London: Westview Press.

Sen AK, 1990. Gender and cooperative conflicts. In : Tinker I, (ed). Persistent inequalities. New York: Oxford University Press.

UNDP, 2011. Human development report 2011 Sustainability and equity: a better future for all.
New York: United Nations Development Programme (UNDP).

Vandaveer C, 2006. What was the cotton of Kush? KillerPlants.com, Plants That Change History Archive.

Van den Broek, E, 2007. Report on sorghum production by Malian women: Its role and importance. Results of Field Research for M. Sc. in International Development Studies, Wageningen University.

Van den Broek E, 2009. Gender in development thinking: The case study of ICRISAT's development initiatives for female sorghum producers in Mali. MSc Thesis, Wageningen University (Wageningen).

Vierich H, 1986. Agricultural production, social status, and intracompound relationships. In : Joyce Lewinger Mook J, (ed). Understanding Africa's rural households and farming systems. Boulder; London: Westview Press.

Wakhungu JW, 2010. Gender dimensions of science and technology: African women in agriculture. Expert Paper. Expert Group Meeting Gender, Science and Technology. Paris, France 28 September - 1 October 2010. United Nations Division for the Advancement of Women (DAW part of UN Women) United Nations Educational, Scientific and Cultural Organization (UNESCO). EGM/ST/2010/EP.2 October 2010.

World Bank, 2011. Africa Development Indicators 2011. Washington (DC): World Bank. 